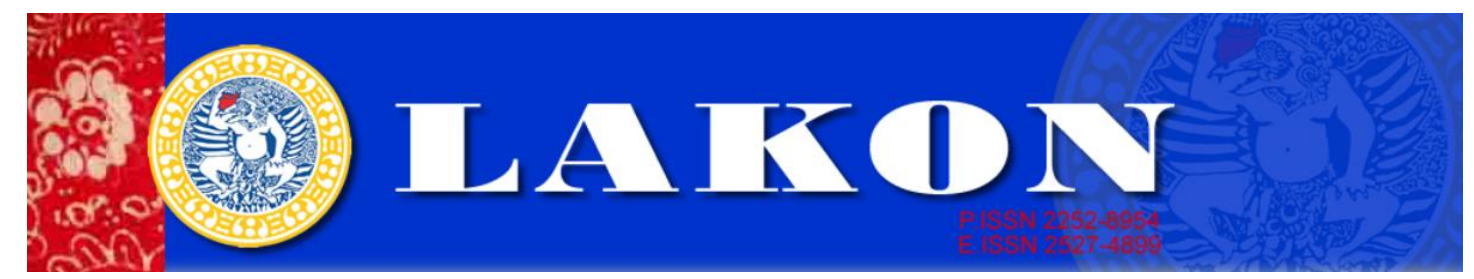

Jurnal Lakon, 9 (1) 2020. 1-8

DOI: 10.20473/lakon.v9i1.19809

\title{
SEMIOTICS OF STOPPING BY WOODS ON SNOWY EVENING
}

Semiotika Puisi Stopping by Woods on Snowy Evening

\section{Agung Wijianto}

\author{
Program Studi Magister Kajian Sastra dan Budaya \\ Fakultas Ilmu Budaya Universitas Airlangga \\ Jl. Dharmawangsa Dalam Selatan, Surabaya 60286 \\ agung.wijianto-2018@fib.unair.ac.id
}

\begin{abstract}
Poetry is one of the fundamentals in literature. It expresses meaning through words and communicates deeper ideas within it. Robert Frost was one of the most prominent poets of all time. His work Stopping by Woods on a Snowy Evening was one of his greatest work, it revolves around the beauty of a forest in the winter. On the surface, it may look like a simple straightforward poem; however, it contains a deeper underlying meaning. Semiotics of Poetry written by Riffaterre will be essential in this paper to dissect the poem. There are various concepts that will be applied in the dissecting the poem like indirection, heuristic and hermeneutics reading, matrix, model, variants, and hypogram. This paper seeks to find the deeper understanding of the poem rather than just a surface understanding of it.
\end{abstract}

Keywords: Poetry, semiotics, heuristic, hermeneutics

Abstrak: Puisi adalah salah satu bagian penting dalam sastra. Puisi mengekspresikan makan melalui kata yang menyampaikan gagasan yang mendalam di dalamnya. Robert Frost merupakan salah satu penyair paling dikenal sepanjang masa. Karyanya yang berjudul Stopping by Woods on a Snowy Evening, yang dikenal sebagai salah satu karya terbaiknya, mengisahkan tentang keindahan di musim dingin. Puisi ini terkesan sederhana di permukaan tetapi menyimpan makna yang mendalam. Teori Semiotika Puisi yang digagas oleh Riffatere digunakan dalam tulisan ini untuk mengkaji puisi tersebut. Ada beberapa konsep yang diaplikasikan pada kajian ini yaitu indirection, heuristic dan hermeneutics reading, matrix, mode, variants dan hypogram. Penelitian ini bertujuan untuk mencari pemaknaan kritis terhadap puisi Stopping by Woods on a Snowy Evening.

Kata Kunci: Puisi, semiotic, heuristic, hermeneutic 


\section{Introduction}

Poetry is one of the main fundamentals of literature besides prose and drama. It has played a huge role in developing literature as a whole. In the old times, poems were considered the highest form of words and language (Shelley, 1820). One of the unique characteristic of a poem is that it combines words and expression to communicate something deeper like ideas or images. It is profound that it is the result of an observation of the universe and the surroundings. Poetry itself has developed over time, forming new structures, written in many different eras, each stylistically different from the others. Arguably, one of the best poems ever written in modern era is Stopping by Woods on Snowy Evening by Robert Frost.

Robert Frost was one of the most prominent poets of modern era. He had won several Pulitzer prizes for his work in poetry. Stopping by Woods on Snowy Evening was considered a classic; it is one monumental work of natural poem. It mainly tells about the beauty of a snowy forest with a man standing there to appreciate the splendor. In a first glance, the poem seems to be straightforward, a description of natural beauty and a man observing it. However, looking at it closely, there are allegorical meanings to which Frost wrote the poem; it pertains to struggle, temptation, and resolution. Thus, it is highly reasonable to analyze this poem and search the underlying meaning by the means of Semiotics of Poetry, a theoretical framework proposed by Michael Riffaterre.

Riffaterre has written a book entitled the Semiotics of Poetry in which he proposed a theoretical framework of analyzing poetry. Riffaterre (in Pradopo, 1999) explained that there are four major points of poetics. They are 1.) Indirection of Signs, 2.) Heuristic and Hermeneutics Reading, 3.) Model, Matrix, and Variant, and 4.) Hippogram or Intertextual Relations. Riffaterre (1978) also argues that poem is "not the raw stuff of language; it is already a stylistic structure, hot with intensified connotation, overloaded conscience" (1978:164).

The goal of this study is to find the allegorical meaning on the Stopping by Woods on Snowy Evening by the methods proposed by Riffaterre. It is assumed that the poem has a deeper and larger meaning to what seems to be a simple nature poem.

\section{Research Methods}

This research employs a qualitative method of descriptive. According to Syaodih (2007) Qualitative method is used to analyze and describe phenomena, happenings, paradigm, social turbulence which is complex and 
need a broader explanation. Poems are complex pieces of literature formed by language, rich of meanings as Riffaterre argues that "a poem says one thing and mean another" (1978:1). Endraswara (2013:176) argues that descriptive method depicts the data as it is in the literature critics. The data for this study is gathered by doing a library research, from which it was documented. This includes the poem itself and the literature needed to build the theoretical framework. The theoretical framework of Riffatere's Semiotics of Poetry is then used to analyze the data collected. The four major points to analyze poetry will be discussed further in the next chapter.

\section{Literature Review}

In the Semiotics of Poetry, Riffaterre (1978) has argued that the method of understanding and reading poems is different from other works. Even though poetry may contain or use the same language as what people use in their daily life, the poem may say one thing but its meaning totally differs. Therefore, Riffaterre suggests a method of analyzing poetry.

I therefore submit the difference we perceive empirically between poetry and non-poetry is fully explained by the way a poetic text carries meaning. It is my purpose here to propose a coherent and relatively simple description of the structure of meaning in a poem. (Riffaterre, 1978, p. 1)

There are four major principal concepts to be used in analyzing poetry. Those four concepts proposed are as follows.

\section{Indirection}

The basic principle of Riffatere's concept for indirection has three ways to produce it. The first way is called a displacing, which happens when one word or phrase may stand for another meaning, mostly happen in metaphor or metonym. An example of this is The man was a lion. The man was not literally a lion; the lion here is nothing but an expression explaining that the man might be fierce, brave, or strong. Another way of indirection other than displacing is distortion.

The second way of producing indirection mentioned by Riffatere is distorting. It happens when one meaning has fuzzy connotation, having more than one meaning, an ambiguity. In addition to that, it also can be created by contradiction by the usage of irony, antithesis, or paradox. One example of irony is as smooth as a rocky cliff. It is already known that rocky cliff is not smooth at all, it is written using irony to invoke sarcasm, or to be playful while indicating a different meaning. 
The last way of producing indirection is called creating. It is employed by using stanzas, symmetry, rhyme, things that has no meaning if they are put on their own. Rhyme by itself has no meaning, however, when it is written gracefully in a poem, it might suggest the musicality of the holistic of a poem.

\section{Heuristic and Hermeneutics}

Heuristic is the first stage of a reading. The first stage of interpretation of the text happens here. However, to be able to interpret the text, the reader must possess some degree of linguistic competence and literary competence as well. Linguistic competence is needed to perceive and notice ungrammaticality and it is also needed to make sense of words or phrases that has no literal meaning. This is done by employing metaphors or other figures to understand it. In addition to a linguistic competence, a reader must have the literary competence to understand the general theme of a poem, its mythologies, and other text that has been written previously. After this first stage, thus the reader can proceed into the second stage, the hermeneutic reading.

Hermeneutic reading, also a retroactive reading, is the second stage of reading that is done to give interpretation of a text; this is the second semiotic stage. In the process of the retroactive reading, the readers keep being reminded by what he has read, constantly restructuring his understanding throughout progress of the decoding. By this process, the reader will find the unit of significance in the second level of semiotics or the allegorical meaning.

\section{Matrix, Model, Variants}

Riffaterre (1978:19-21) has argued that poetry consists matrix. Matrixes are not explicitly written in poems. It is also not necessarily the theme, but it pertains to the theme. By finding the matrix, then the theme can be found. The semiotic system in the poems is based on the matrix, from which it is then transformed into models.

From the matrix as the base of the semiotic system, models then can be derived from the matrix. It may have the form of figurative language, or as a symbol, a sign, or image. From these models, the variants of the model can be further by formed.

\section{Hypogram}

To give a deeper understanding in the significance of poems, the literary work has to be aligned with another work or a background. This other work or the background is its hypogram, a response to the work itself (Riffaterre, 1978). This response may manifest in the form of 
opposition, continuance, appreciation, or even critics. The response becomes the base of the creation of the poem. This hypogram may be based on social society, previous literature, natural elements, and historical events. By finding the hypogram, the critic may understand the significance of the whole poem.

\section{Discussion and Findings}

\section{Stopping by Woods on a Snowy Evening}

By: Robert Frost

Whose woods these are I think I know. His house is in the village though; He will not see me stopping here To watch his woods fill up with snow.

My little horse must think it queer To stop without a farmhouse near Between the woods and frozen lake The darkest evening of the year.

He gives his harness bells a shake To ask if there is some mistake. The only other sound's the sweep

of easy wind and downy flake.

The woods are lovely, dark and deep,

But I have promises to keep, And miles to go before I sleep, And miles to go before I sleep.

Stopping by Woods on a Snowy Evening is one of the greatest works ever written by Robert Frost. It can be seen that the persona in the poem is in awe of what he is seeing, the magnificence of his surroundings. However, if it is only inferred what the poem says about the beauty of the nature, the significance of this poem becomes shallow and lacking of deeper meaning. The method proposed by Riffaterre will be used to scrutinize this poem so that a deeper meaning of struggle, confusion, or even the classic theme of Man versus Nature can be surmised.

\section{Indirection}

The indirection of meaning which Riffaterre suggests that there are three ways for it to happen. Those three ways are displacing, distortion, and creation. There is a certain displacing used by the author to express meaning by employing metonym. That is written in second line of the first stanza. The word village here does not really mean a rural place, but rather a home, a place where the persona lives his life. In addition to displacing, the poet also employs distortion in the poem.

The poet employs two distortions for the significance of the poem. In the last line of the third stanza, the phrase easy wind is a continuation from the previous line the only other sound's the sweep. It can be seen the incongruence that happen in these two lines; because the wind is presumably not easy, but rather hard since it produces 
sounds. An irony here is utilized to create distortion. The second distortion happening in the poem is done by making use of antithesis. It is written in the first line of the fourth stanza the words lovely; dark and deep. These two words juxtaposes each other, usually something that is dark is a horror or creepy thing. The persona suggests otherwise. The darkness and the depth of the woods entice him into staying.

\section{Heuristic and Hermeneutic Reading}

The first stage of interpretation of the poem is done by heuristic reading. Linguistically, there are some irregularities found in this poem. An example of this can be found in the first line "whose woods these are I think I know", the auxiliary word here is inverted. It can be inferred that the persona here is confused that he even messes up his grammar, something that he should be familiar. Another example of this can also be found in the 4th stanza, first line, the poet omitted a comma in the line "the woods are lovely, dark and deep". The absence of a comma between "dark" and "deep" suggests that "dark and deep" is a unity that the depth and the darkness are lovely. In literary level, we can see the general theme inferred is the struggle of a man in the nature. The temptation, beauty, and the challenge of the woods and the cold of a snowy evening are so challenging that they make the man stop from his journey.

Hermeneutic reading or a retroactive reading should be done to understand the whole meaning of a text while keep restructuring it. As Riffaterre suggests (1978), that reading hermeneutics is completed by "perceiving the work as a part of a complex network" (p. 6). Doing a retroactive reading, the meaning of the theme is further reinforced from the start to the finish. In the start, the persona in the poem feeling confused and it then begins to shift to other character. Towards the end of the poem, the poem also explains about the resolution of the poem although it is unclear how his journey shall end. The constant struggle between the man and the nature is the core essence of the poem, resembling the continuous struggle of human throughout his life in the nature.

\section{Matrix, Model, and Variants}

Theoretically, words and phrases in a poem are the development of a matrix that has been transformed into models. The models will then be transformed to many different variants. By performing the heuristic reading and hermeneutic reading, it can safely be assumed that the matrix in this poem would be "beauty of nature". All of the four stanzas explain about the environmental splendor like woods accompanied with snow, frozen lake in the 
evening, lake with a wind breeze, the lovely woods. It feels like the image of those beauties pops vividly in the mind in the process of reading it and the word that comes with it is simple, beautiful.

From the nucleus of the matrix, the transformation to the model begins. The model in this poem can be deduced as the struggle of a man versus the nature. This model becomes the basis of all the subsequent variants. In the first stanza, we can find the first variants, the man stopped in his journey to ponder and contemplate the magnificence. After that, the second stanza suggests that the horse, his companion, is also confused by what his master is doing, stopping in the middle of the woods. The third stanza follows that, suggesting that the horse tries to awake his master by shaking profusely and ringing its bell. The horse tries to rouse his master to continue their journey. The last stanza of the poem suggests the resolution of the man. Even though in the first two lines the man is still fixated on the nature, the last two lines suggest that the man starts to resolute himself into continuing his journey. He opts to fulfill his promise.

The matrix, the model, and the variants from this poem conjecture the findings of the general theme of this poem holistically. The continuous struggle of a man against nature is the core essence of the poem. How a man can resist temptation from his environment. After the battle, the man starts to decide to stay true to his obligation, finishing his journey, fulfilling his promises in the real life. This poem is a reflection of a huge classical work since all time, the struggle of a man in his journey of life.

\section{Hypogram}

Hypogram is the background of the creation of an artwork. Judging from the general theme of the poem and the expressions written in the text, it can be inferred that the hypogram behind this piece of work is the natural beauty of forest in a winter season. This becomes the source of inspiration for the poem. In addition to that, the upbringing of the poet also can be assumed in being the hypogram of this poem. The theme of the struggle of life could be the reflection of the poet's life.

\section{Conclusion}

The poem Stopping by Woods on a Snowy Evening is a monumental work. It is so charming with its endearing qualities. In a glance, the poem is nothing more than just a descriptive work of a man appreciating beauty of the nature. However, in a deeper level of understanding and reading, the underlying meaning of a struggle of man to the nature, its temptation, its beauties, its depth and darkness 
proves to be grand in this poem. This poem also reflects the optimistic mind of the poet not to give up to the temptation, but rather so resolute about his obligation despite the heavy fights.

\section{References}

Endraswara, Suwardi. (2013). Metodologi Kritik Sastra. Jogjakarta: Penerbit Ombak

Pradopo, Rachmad Djoko. (1999). Semiotika: Teori, Metode, dan Penerapannya dalam Pemaknaan Sastra. Jurnal Humaniora, 11 (1), 76 - 84. doi:http://dx.doi.org/10.221

46/jh.v11i1.628

Riffaterre, Michael. (1978). Semiotics

of Poetry.

Birmingham:Indiana

Universty Press

Shelley, P. B. (1840). The Defence of the Poetry. Essays, Letters from Abroad, Translations and Fragments. London: Edward Moxon.

Syaodih, Nana. (2007). Metode Penelitian Pendidikan. Bandung:Remaja Rosdakarya 